\title{
Phenolic Content and Biomolecule Oxidation Protective Activity of Globularia alypum Extracts
}

\author{
Hamama Bouriche ${ }^{1 *}$, Seoussen Kada ${ }^{1}$, Abderrahmane Senator ${ }^{1}$, Ibrahim demirtas ${ }^{2}$, Tevfik \\ Ozen $^{3}$, Bircan Çeken Toptanci ${ }^{4}$, Goksel Kizil ${ }^{4}$, Murat Kizil ${ }^{4}$. \\ ${ }^{1}$ Laboratory of Applied Biochemistry, Faculty of SNV, University Ferhat Abbas, Sétif 1, Algeria. ${ }^{2}$ Department of \\ Chemistry, Faculty of Science, Cankirl Karatekin University, Cankırl, Turkey. ${ }^{3}$ Department of Chemistry, Faculty of \\ Science and Arts, Ondokuz Mayis University, Samsun, Turkey. ${ }^{4}$ Department of Chemistry, Faculty of Science and \\ Arts, University of Dicle, Diyarbakir, Turkey
}

\begin{abstract}
The protective activity of methanolic (Met E) and aqueous (Aq E) extracts of Globularia alypum L. (G. alypum) against DNA, lipid and protein oxidative damage was investigated. Moreover, the scavenging, chelating, and reducing power activities of the extracts were also evaluated. Phytochemical analysis was performed to determine phenolic compounds. Results showed that Met E and Aq E were rich in phenolic compounds, and were able to scavenge DPPH ${ }^{*}$ with $I_{50}$ values of $48.61 \mu \mathrm{g} / \mathrm{mL}$ and $51.97 \mu \mathrm{g} / \mathrm{mL}$, respectively. In addition, both extracts were able to chelate ferrous ions. At $300 \mu \mathrm{g} / \mathrm{mL}$, the chelating activity was $97.53 \%$ and $91.02 \%$, respectively. The reducing power of these extracts was also remarkable and concentration dependent. At $100 \mu \mathrm{g} / \mathrm{mL}$, both extracts inhibited lipid peroxidatin by only $42.45 \%$ and $4.03 \%$. However, the DNA oxidation damage was inhibited dosedependently in the presence of G. alypum extracts. At $1 \mathrm{mg} / \mathrm{mL}$, both extracts suppressed DNA cleavage by 83\%84\%. The protein oxidation was also inhibited by G. alypum extracts. At $1 \mathrm{mg} / \mathrm{mL}$, Aq E and Met E protected BSA fragmentation by $77 \%-99 \%$. The overall results suggest that G. alypum extracts exerted antioxidant activity and protect biomolecules against oxidative damage; hence it may serve as a potential source of natural antioxidants.
\end{abstract}

Key words: antioxidants, DNA damage, Globularia alypum, lipid peroxidation, protein oxidation

\footnotetext{
*Author for correspondence: bouriche_ha@yahoo.fr
} 


\section{INTRODUCTION}

Reactive oxygen species (ROS) generation, results from a number of endogenous metabolic pathways, as well as from exposure to chemical and physical factors in the ambient environment. In small amounts, ROS play important roles in a number of biological processes and regulate cell physiology and functions. They act as signal transducers ${ }^{1,2}$, growth factor regulators ${ }^{3,4}$, second messengers and regulators of vascular homeostasis ${ }^{5}$. However, the overproduction of ROS leads to several cell damaging effects. Cells have a variety of defense mechanisms that intercept ROS to prevent or limit intracellular damages and ameliorate their harmful effects. When the equilibrium between pro-oxidant and antioxidant systems within the cell is failed, the overproduced ROS, which could not be fully neutralized can cause oxidative damage to a broad range of cell components, leading to many diseases ${ }^{6}$. ROS can interact and modify different classes of biological macromolecules including DNA, lipids and proteins.

ROS can react with the polyunsaturated fatty acids of lipid membranes and induce lipid peroxidation. Lipid peroxidation is a source of secondary free radicals, which can directly react with other biomolecule, enhancing biochemical lesions ${ }^{7}$. Increased formation of oxidized lipid products contribute to several pathologies such as atherosclerosis, ischemia-reperfusion, heart failure, Alzheimer's disease, rheumatic arthritis, cancer, and other immunological disorders ${ }^{8}$. Moreover, lipid peroxidation is one of the major factors causing deterioration of foods during storage and processing, and could have harmful effects on human health ${ }^{9}$.

DNA is continually attacked by ROS that can affect its structure and function severely. Excess oxidative stress results in DNA base modifications, single- and double-strand breaks, and the formation of apurinic/apyrimidinic lesions, which may be toxic and/or mutagenic ${ }^{10}$. Mutagenic lesions are a critical contributor to the development of aging, some degenerative diseases ${ }^{11,12}$, and many cancers ${ }^{13,14}$

Proteins are also major targets for ROS attacks in biological systems due to their abundance and high rate constants for reaction. During oxidation, several amino acid residues irreversibly form carbonyl products, which can further lead to the formation of high-molecular-mass aggregates ${ }^{15}$. Protein aggregates can be highly cytotoxic, altering cell functions and leading to cell necrosis or apoptosis ${ }^{16}$. The accumulation of oxidized proteins was observed in several pathological states such as diabetes, neurodegenerative diseases and aging ${ }^{12,17,18}$.

Medicinal plants constitute one of the main sources of safe antioxidants, healthcare supplements and phytochemicals that assist in maintaining good health and combating diseases. Globularia alypum L. is an aromatic medicinal plant belongs to Globulariaceae family, found throughout the Mediterranean area and largely used in Algerian folk medicine to treat some inflammatory disorders. The leaves of the plant are reported to be used in the treatment of diabetes, renal disorders and cardiovascular diseases ${ }^{19,20}$. However, few studies are reported on the phytochemical constituents and the biological activities of this plant. Moreover, the literature survey did not reveal any reference to previous work comparing the antioxidant activities of this plant by reducing biomacromolecule oxidative damages. Therefore, this study is aimed to investigate the antioxidant activity and the potential role of methanolic and aqueous extracts of G. alypum L. to prevent lipid, DNA and proteins against oxidative damages.

\section{MATERIALS AND METHODS}

\section{Chemicals}


Anti-oxidative damage of plant extracts

Ascorbic acid, bovine serum albumin (BSA), 1,1-Diphenyl-2-picrylhydrazyl (DPPH), ethidium bromide, $\mathrm{FeCl}_{2}, \mathrm{FeCl}_{3}, \mathrm{FeSO}_{4}$, folin-ciocalteu reagent, gallic acid, $\mathrm{H}_{2} \mathrm{O}_{2}$, linoleic acid, sodium carbonate $\left(\mathrm{Na}_{2} \mathrm{CO}_{3}\right)$, thiobarbituric acid (TBA), trichloroacetic acid(TCA), tween-20, potassium ferricyanide $\left(\mathrm{K}_{3} \mathrm{FeCN}_{6}\right)$ and quercetin, were purchased from Sigma chemical (St. Louis, MO). Plasmid miniprep kit was obtained from Quiagen (Valencia, CA). All other chemicals and solvents were of analytic grade and are from Panreac (Spain), Fluka (French), Riedel-de Haén (Germany).

\section{Plant Material}

Globularia alypum L. was collected in June 2010 from Sétif, in Eastern Algeria. The plant was identified and authenticated taxonomically by Dr. N. Boulaacheb, Univesity of Sétif 1, Algeria. A voucher specimen (No. G.A. 2010-1) was preserved at the local Herbarium of Botany, Department of Botany, University of Sétif, Algeria. Leaves were air-dried at room temperature and then reduced to powder.

\section{Preparation of the Plant Extracts}

Globularia alypum methanolic extract (Met E) was prepared by maceration of $100 \mathrm{~g}$ of powdered aerial part of the plant material twice with $80 \%$ methanol and then with methanol $50 \%$ at room temperature for $48 \mathrm{~h}$ with frequent agitation. After filtration, the filtrate was concentrated under reduced pressure at $40{ }^{\circ} \mathrm{C}$. The residue was lyophilized to give a brown powder (yield: $37.8 \%$ ) which was stored at $-32{ }^{\circ} \mathrm{C}$ until use.

Aqueous extract (Aq E) was prepared by boiling $50 \mathrm{~g}$ of powdered plant in $500 \mathrm{~mL}$ of distillated water for $20 \mathrm{~min}$. After filtration, the filtrate was lyophilized to give a brown powder (yield: $30 \%$ ).

\section{Determination of Total Polyphenols}

The content of total polyphenolic compounds in the extracts was determined using Folin-Ciocalteu's reagent according to Li et al. ${ }^{21}$. Sample of $40 \mu \mathrm{L}$ of crude extract $(1 \mathrm{mg} / \mathrm{ml})$ were mixed with $200 \mu \mathrm{L}$ of Folin-Ciocalteu reagent and $1160 \mu \mathrm{L}$ of distilled water, followed by the addition of $600 \mu \mathrm{L}$ of $7.5 \% \mathrm{Na}_{2} \mathrm{CO}_{3}$. The mixtures were shaken for $2 \mathrm{~h}$ at room temperature and the absorbance was measured at 765 $\mathrm{nm}$. Gallic acid was used as a standard. The concentration of total polyphenol compounds was determined as $\mathrm{mg}$ of Gallic acid equivalents per $1 \mathrm{~g}$ of extract (GAE/mg extract).

\section{Determination of Total Flavonoids}

The method of Bahorun et al. ${ }^{22}$ was used to determine the total flavonoid content of G. alypum extracts. Briefly, $1 \mathrm{~mL}$ of $2 \% \mathrm{AlCl}_{3}$ (in ethanol) was added to $1 \mathrm{~mL}$ of each extract $(1 \mathrm{mg} / \mathrm{mL})$. After $10 \mathrm{~min}$ of incubation at room temperature, the absorbance was measured at $430 \mathrm{~nm}$. Quercetin was used as a standard. Total flavonoid content was expressed as mg quercetin equivalent per $g$ of extract (QAE/g extract).

\section{Determination of Total Condensed Tannins}

Tannin content of the extracts was determined using the hemoglobin precipitation assay according to Bate-Smith ${ }^{23}$, using tannic acid as standard. An aliquot of $0.5 \mathrm{~mL}$ of each extract is mixed with $0.5 \mathrm{~mL}$ of hemolysis bovine blood to reach a final concentration of $1 \mathrm{mg} / \mathrm{mL}$, then the mixture was centrifuged at $480 \mathrm{~g}$ for $20 \mathrm{~min}$ and 
the absorbance was measured at $578 \mathrm{~nm}$. Tannin content was expressed as $\mathrm{mg}$ tannic acid equivalent per $\mathrm{g}$ of extract (TAE/g extract).

\section{HPLC-TOF/MS Analysis}

Phenolic acids and flavonoids in the extracts were analyzed by e HPLC-TOF/MS using Agilent Technology of 1260 Infinity HPLC System coupled with 6210 Time Of Flight (TOF) LC/MS detector and ZORBAX SB-C18 (4.6 x $100 \mathrm{~mm}, 3.5 \mu \mathrm{m})$ column as described by Abay et al. ${ }^{24}$. Mobile phases A and B were ultra-pure water with $0.1 \%$ formic acid and acetonitrile, respectively. Flow rate was $0.6 \mathrm{~mL} \mathrm{~min}{ }^{-1}$ and column temperature was $35^{\circ} \mathrm{C}$. Injection volume was $10 \mu \mathrm{L}$. The solvent program was as follow: $0-1 \min 10 \% \mathrm{~B}$; $1-20 \min 50 \% \mathrm{~B}$; $20-23 \min 80 \% \mathrm{~B}$; $23-25 \min 10 \%$ $\mathrm{B} ; 25-30 \mathrm{~min} 10 \% \mathrm{~B}$. Ionization mode of HPLC-TOF/MS instrument was negative and operated with a nitrogen gas temperature of $325^{\circ} \mathrm{C}$, nitrogen gas flow of $10.0 \mathrm{~L}$ $\mathrm{min}^{-1}$, nebulizer of $40 \mathrm{psi}$, capillary voltage of $4000 \mathrm{~V}$ and finally, fragmentor voltage of $175 \mathrm{~V}$. For sample analysis, dried crude extracts (200 ppm) were dissolved in methanol at room temperature. Samples were filtered through a PTFE $(0.45 \mu \mathrm{m})$ filter by an injector to remove particulates.

\section{Free Radical Scavenging Activity}

Free radical scavenging activity of the extracts was measured according to the method of Que et al. ${ }^{25}$. The solution of the free DPPH radical in ethanol $(0.1 \mathrm{mM})$ was prepared and $0.5 \mathrm{~mL}$ of aqueous or methanolic extracts at different concentrations $(10-400 \mu \mathrm{g} / \mathrm{mL})$ was added. The mixture was shaken vigorously and left standing at room temperature for $30 \mathrm{~min}$. before measuring the absorbance at $517 \mathrm{~nm}$. Butylated hydroxytoluene (BHT) was used as a standard antioxidant. The antiradical activity was expressed as $\mathrm{IC}_{50}\left(\mathrm{mg} \cdot \mathrm{mL}^{-1}\right)$. A lower $\mathrm{IC}_{50}$ value corresponds to a higher antioxidant activity of extracts. The ability to scavenge the DPPH radicals was calculated using the following equation:

$\mathrm{DPPH}^{*}$ scavenging activity $(\%)=\left[\left(\mathrm{A}_{0}-\mathrm{A}_{1}\right) / \mathrm{A}_{0}\right] \times 100$

Where $A_{0}$ is the absorbance of the control and $\mathrm{A}_{1}$ is the absorbance of the sample at $30 \mathrm{~min}$.

\section{Ferrous Ions Chelating Activity}

The chelating of ferrous ions by the methanolic and aqueous extracts was estimated by the method of Le et al. ${ }^{26}$. Briefly the extract samples $(20-300 \mu \mathrm{g} / \mathrm{mL})$ were added to $50 \mu \mathrm{l}$ of $0.6 \mathrm{mmol} / \mathrm{l} \mathrm{FeCl}_{2}$. The reaction was initiated by the addition of 50 $\mu \mathrm{L}$ of ferrozine $(5 \mathrm{mM})$ and the mixture was shaken vigorously and left standing at room temperature for $10 \mathrm{~min}$ before measuring the absorbance at $562 \mathrm{~nm}$. EDTA was used as a standard chelator. The percentage of inhibition of ferrozine- $\mathrm{Fe}^{2+}$ complex formation was calculated using the following formula:

Ferrous ions chelating activity $(\%)=\left[\left(\mathrm{A}_{0}-\mathrm{A}_{1}\right) / \mathrm{A}_{0}\right] \times 100$

Where $\mathrm{A}_{0}$ is the absorbance of the control (contained complex formation molecules; $\mathrm{FeCl}_{2}$ and ferrozine) and $\mathrm{A}_{1}$ is the absorbance of the test compound.

\section{Reducing Power}

The reducing power of G. alypum extracts was determined according to the method of Oyaizu ${ }^{27}$. A volume of $2,5 \mathrm{~mL}$ of each each extract at different concentration (20 $-350 \mu \mathrm{g} / \mathrm{mL}$ ) was mixed with $2.5 \mathrm{~mL}$ of $200 \mathrm{mM}$ sodium phosphate buffer ( $\mathrm{pH} 6.6$ ) and $2.5 \mathrm{~mL}$ of $1 \%$ potassium ferricyanide. After the incubation of the mixture at $50^{\circ} \mathrm{C}$ for $20 \mathrm{~min}, 2.5 \mathrm{~mL}$ of $10 \%$ TCA were added and the mixture was centrifuged at $200 \times \mathrm{g}$ for $10 \mathrm{~min}$. The upper layer $(2.5 \mathrm{~mL})$ was mixed with $2.5 \mathrm{~mL}$ of deionized water and $0.5 \mathrm{~mL}$ of $0.1 \% \mathrm{FeCl}_{3}$ and the absorbance was measured at $700 \mathrm{~nm}$. Higher absorbance indicates higher reducing power. The assays were carried out in 
triplicate and the results are expressed as mean values \pm standard deviations. BHT was used as a standard antioxidant.

\section{Linoleic Acid Peroxidation Assay}

The protective effect of $G$. alypum extracts against lipid peroxidation was tested by assessing the peroxidation of linoleic acid in an oxidation system catalysed by $\mathrm{Fe}^{+2}$ ascorbate ${ }^{28}$. Different concentrations $(50-500 \mu \mathrm{g} / \mathrm{mL})$ of extracts were mixed with linoleic acid solution $(0.28 \mathrm{mg}$ linoleic acid and $0.28 \mathrm{mg}$ tween-20) in $500 \mathrm{~mL}$ of $100 \mu \mathrm{M}$ of phosphate buffer ( $\mathrm{pH} 7.4$ ) and $150 \mu \mathrm{L}$ of $10 \mu \mathrm{M}$ ascorbic acid solution. The mixture was mixed and sonicated to obtain a homogeneous emulsion. The linoleic acid peroxidation was initiated by the addition of $0.1 \mathrm{~mL} \mathrm{FeSO}_{4}(10 \mu \mathrm{M})$. After incubation at $37 \mathrm{C}^{\circ}$ for $60 \mathrm{~min}$, the mixture was cooled and $1.5 \mathrm{~mL}$ of TCA $(10 \%$ in $0.5 \% \mathrm{HCl})$ was added, followed by the addition of $3 \mathrm{~mL}$ of TBA $(1 \%$, in 50 $\mathrm{mM} \mathrm{NaOH})$. The mixture was then heated in a water bath at $90 \mathrm{C}^{\circ}$ for $60 \mathrm{~min}$. After cooling, aliquots of $2 \mathrm{~mL}$ were taken from each sample and mixed with $2 \mathrm{~mL}$ of butanol and centrifuged at $1000 \mathrm{x} \mathrm{g}$ for $30 \mathrm{~min}$. The upper layer solution was separated for measuring the absorbance at $532 \mathrm{~nm}$. The percentage of linoleic acid peroxidation inhibition was calculated according to the following equation:

Linoleic acid peroxidation inhibition $(\%)=\left[\left(\mathrm{A}_{0}-\mathrm{A}_{1}\right) / \mathrm{A}_{\mathrm{o}}\right] \times 100$

Where $A_{o}$ is the absorbance of control reaction (containing all reagents except the extracts) and $\mathrm{A}_{1}$ is the absorbance of the sample with extracts or standard.

\section{DNA Oxidation Assay}

Protective activity of methanolic and aqueous extracts of G. alypum against DNA damage was tested by photolysing $\mathrm{H}_{2} \mathrm{O}_{2}$ with $\mathrm{UV}$ radiation in the presence of pBluescript M13+ plasmid DNA. Plasmid DNA was isolated by Qiagene plasmid miniprep (and oxidized with $\mathrm{H}_{2} \mathrm{O}_{2}+\mathrm{UV}$ treatment in presence of different concentrations of G. alypum extracts $(100,250,350$ and $500 \mu \mathrm{g} / \mathrm{mL})$ and checked on $1 \%$ agarose gel electrophoresis according to a modified method ${ }^{29}$. Briefly, the experiments were performed in a volume of $10 \mu \mathrm{L}$ in a microcentrifuge tube containing $200 \mathrm{ng}$ of plasmid DNA in phospate buffer $(7.14 \mathrm{mmol}$ phospate and $14.29 \mathrm{mmol} \mathrm{NaCl}, \mathrm{pH}$ 7.4) and $\mathrm{H}_{2} \mathrm{O}_{2}$ was added at a final concentration of 2.5 $\mathrm{mmol} / \mathrm{L}$ with or without $1 \mu \mathrm{L}$ of extracts. The reactions were initiated by UV irradiation and continued for $5 \mathrm{~min}$ on the surface of a UV transilluminator with intensity $8000 \mu \mathrm{W} / \mathrm{cm}^{2}$ at $300 \mathrm{~nm}$ under room temperature. After irradiation, the reaction mixture $(10 \mu \mathrm{L})$ with gel loading dye was placed on $1 \%$ agarose gel for electrophoresis. Electrophoresis was performed at $40 \mathrm{~V}$ for $3 \mathrm{~h}$ in the presence of ethidium bromide $(10 \mathrm{mg} / \mathrm{mL})$. Untreated pBluescript M13+ plasmid DNA was used as a control in each run of gel electrophoresis along with partial treatments (i.e. only UV treatment and only $\mathrm{H}_{2} \mathrm{O}_{2}$ ). Percent inhibition of the DNA strand scission was calculated as follows:

Inhibition $(\%)=\mathrm{I}-(\mathrm{Sm}+\mathrm{a}-\mathrm{Sc}) /(\mathrm{Sm}-\mathrm{Sc})$.

Where $\mathrm{Sm}+\mathrm{a}$ is percentage remaining supercoiled DNA after treatment with UV + $\mathrm{H}_{2} \mathrm{O}_{2}$ in the presence of the extracts, $\mathrm{Sc}$ is percentage remaining supercoiled DNA in the control untreated plasmid, and $\mathrm{Sm}$ is percent remaining supercoiled DNA with $\mathrm{UV}+\mathrm{H}_{2} \mathrm{O}_{2}$ without extracts.

Treated and untreated pBluescript M13+ plasmid DNA gel was scanned using Gel Documentation System (Gel-Doc-XR; BioRad, Hercules, CA, USA). Bands on the gels were quantified by discovery series Quantity One programme (version 4.5.2, BioRad Co.). 


\section{Protein Oxidation Assay}

The protective ability of methanolic and aqueous extracts of G. alypum against protein oxidation was evaluated according to Kizil et al. ${ }^{29}$. BSA $(1 \mathrm{mg} / \mathrm{mL})$, used as a model protein, was dissolved in $20 \mathrm{mM}$ potassium phosphate buffer ( $\mathrm{pH}$ 7.4) and then $50 \mu \mathrm{M} \mathrm{FeCl}_{3}, 1 \mathrm{mM} \mathrm{H}_{2} \mathrm{O}_{2}$, and $100 \mu \mathrm{M}$ ascorbic acid were added in the reaction mixture. This mixture was incubated in the presence or absence of methanol and aqueous extracts of G. alypum $(50-1000 \mu \mathrm{g} / \mathrm{mL})$ in a final volume of $1.2 \mathrm{~mL}$ for 3 $\mathrm{h}$ at $37{ }^{\circ} \mathrm{C}$, and then the reaction mixture was analyzed by electrophoresis in $10 \%$ SDS polyacrylamide gel (SDS-PAGE) according to Laemmli (1970). Samples were mixed with equal volumes of sample buffer (Tris $\mathrm{HCl} \mathrm{pH} \mathrm{6.8,} 2 \%$ SDS, $5 \%$ of 2mercaptoethanol, $10 \%$ sucrose, and $0.002 \%$ bromophenol blue). The mixture was then boiled for $5 \mathrm{~min}$, and then $5 \mu \mathrm{L}$ of each sample was electrophoresed by SDSPAGE. The gel was run in a BioRad tank in running buffer $(25 \mathrm{mM}$ Tris $\mathrm{pH} 8.3,190$ $\mathrm{mM}$ glycine, and $0.1 \%$ SDS) at a maximum voltage and a constant current of $25 \mathrm{~mA}$ for a mini gel, using a BioRad 1000/500 power supply. Gels were stained with $0.15 \%$ Coomassie Brillant Blue R-250 for $2 \mathrm{~h}$ and then distained and digitally photographed.

The density of each band, corresponding to the protein fragments was estimated using the Gel Documentation System (Gel-Doc-XR; BioRad, Hercules, CA, USA). Bands on the gels were quantified by Discovery Series Quantity One program (version 4. 5. 2, BioRad Co.).

\section{Statistical Analysis}

Data were analyzed by analysis of variance (ANOVA). $\mathrm{IC}_{50}$ values were calculated by regression analysis. Results were expressed as the mean \pm standard deviation (SD). Difference was considered significant when $P<0.05$.

\section{RESULS}

\section{Total Polyphenol, Flavonoid and Tannin Content}

Total content of phenolic compounds of G. alypum extracts are presented in Table 1. Methanolic extract contains the highest amount of polyphenols, flavonoids and tannins compared to aqueous one.

Table 1. Polyphenol, tannin and flavonoid content of methanolic extract (Met E) and aqueous extract (Aq E) of $G$. alypum.

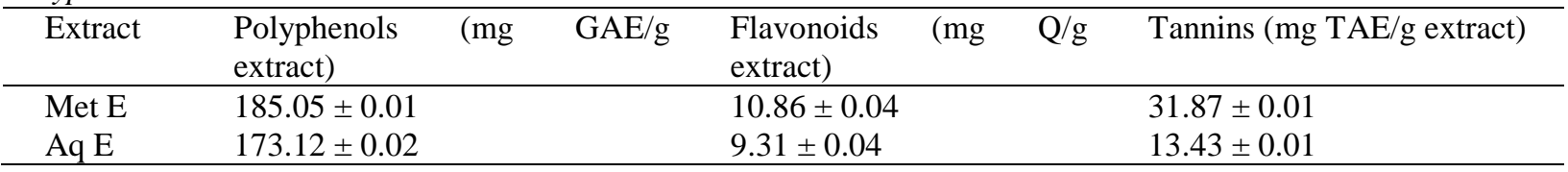

Values are mean of triplicate determination $(n=3) \pm$ SD.

\section{HPLC-TOF/MS Analysis}

The HPLC-TOF/MS analysis revealed the presence of phenolic acids and flavonoids in G. alypum methanolic and aqueous extracts (Table 2 and Fig. 1). Both extracts contain high quantity of glycoside flavonoids such as diosmin, rutin and scutellarin. A highest amount of naringin and quercetin-3- $\beta$-D-glucoside was observed in aqueous extract, while the quantity of all other flavonoids (catechin, rutin, scutellarin, diosmin, neohesperidin and morin) was higher in methanolic extract than that in aqueous extract. Hesperidin was present in a small quantity in aqueous extract and as trace in methanolic extract. Moreover, among the determined phenolic acids, the concentration of cinnamic acid was high in both extracts, whereas protocatechuic acid was only detected in the aqueous extract. 
Anti-oxidative damage of plant extracts

Table 2. Phenolic compounds identified by HPLC-TOF/MS analysis in methanolic extract (Met E) and aqueous extract (Aq E) of G. alypum.

\begin{tabular}{llll}
\hline Compounds & $\begin{array}{l}\text { RT } \\
(\mathrm{min})\end{array}$ & $\begin{array}{l}\text { Met E } \\
\text { mg phenolic/kg plant }\end{array}$ & $\begin{array}{l}\text { Aq E } \\
\text { mg phenolic/kg plant }\end{array}$ \\
\hline Gentisic acid & 4.42 & 21.39 & 23.31 \\
Catechin & 5.23 & 30.99 & 25.67 \\
4-hydroxybenzoic acid & 6.82 & 3.46 & 14.64 \\
Protocatechuic acid & 6.98 & $\mathrm{Nd}$ & 39.53 \\
Vanillic acid & 8.51 & 25.26 & 19.00 \\
Cinnamic acid & 15.78 & 137.77 & 213.16 \\
Rutin & 9.02 & 275.24 & 234.43 \\
Scutellarin & 9.21 & 221.77 & 7.96 \\
Quercetin-3- $\beta$-D-glucoside & 10.06 & 39.07 & 347.38 \\
Naringin & 10.30 & 17.54 & 177.74 \\
Diosmin & 10.90 & 381.42 & 233.97 \\
Hesperidin & 10.90 & 0.64 & 2.87 \\
Neohesperidin & 11.84 & 38.09 & 1.54 \\
$P$-coumaric acid & 11.94 & 8.33 & 13.74 \\
Morin & 13.14 & 32.11 & 25.33 \\
\hline RT: & & &
\end{tabular}

RT: retention time; Nd: not determined
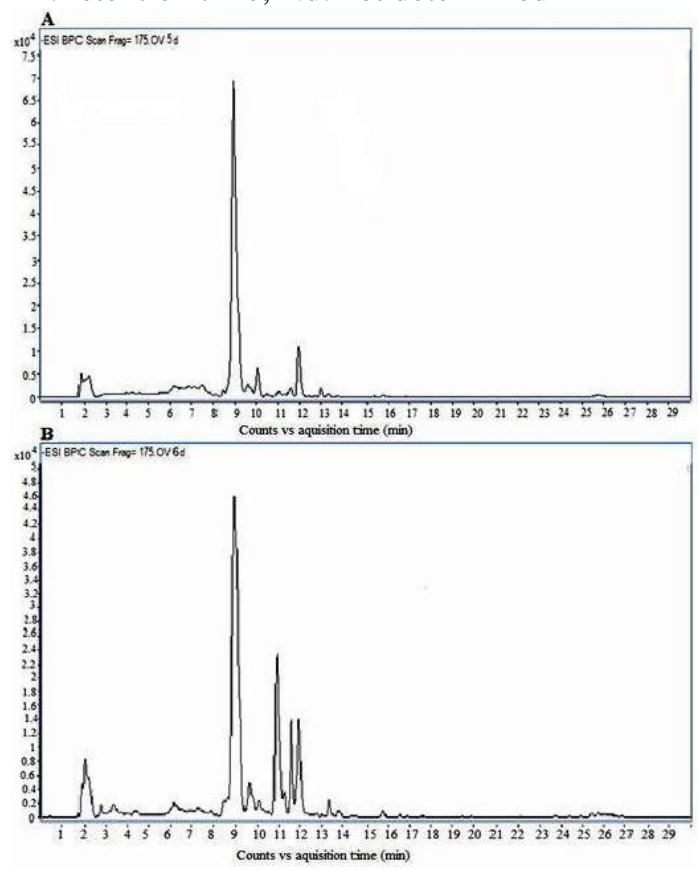

Figure 1 -

Free Radical Scavenging Activity

Globularia alypum extracts showed a concentration-dependent scavenging activity of DPPH free radicals (Fig. 2). However, methanolic extract was more potent than the aqueous one. The recorded $\mathrm{IC}_{50}$ were $48.61 \mu \mathrm{g} / \mathrm{mL}$ and $51.97 \mu \mathrm{g} / \mathrm{mL}$, respectively. The activity of methanolic extract was close to that of the standard antioxidant BHT $\left(\mathrm{IC}_{50}=44.35 \mu \mathrm{g} / \mathrm{mL}\right)$. 


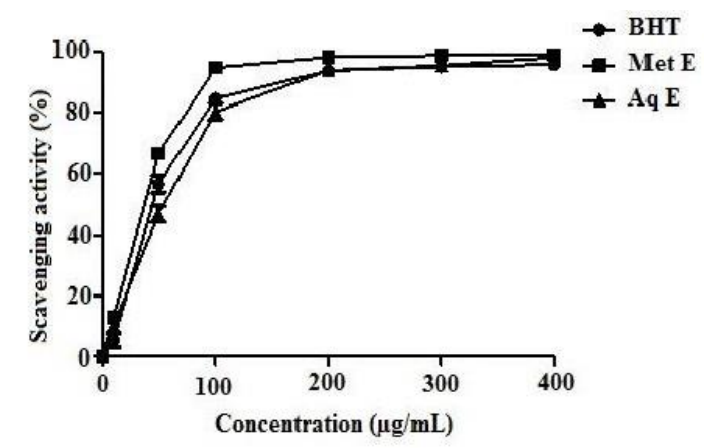

Figure 2 -

\section{Ferrous Ions Chelating Activity}

The methanolic and aqueous extracts of G. alypum were able to chelate ferrous ions in a concentration-dependent manner (Fig. 3). However, the aqueous extract showed more activity than the methanolic extract. The $\mathrm{IC}_{50}$ values were $52.69 \mu \mathrm{g} / \mathrm{mL}$ and $148.15 \mu \mathrm{g} / \mathrm{mL}$, respectively. This activity was less important than that obtained with the standard chelator, EDTA, which gave an $\mathrm{IC}_{50}$ value of $5.97 \mu \mathrm{g} / \mathrm{mL}$.

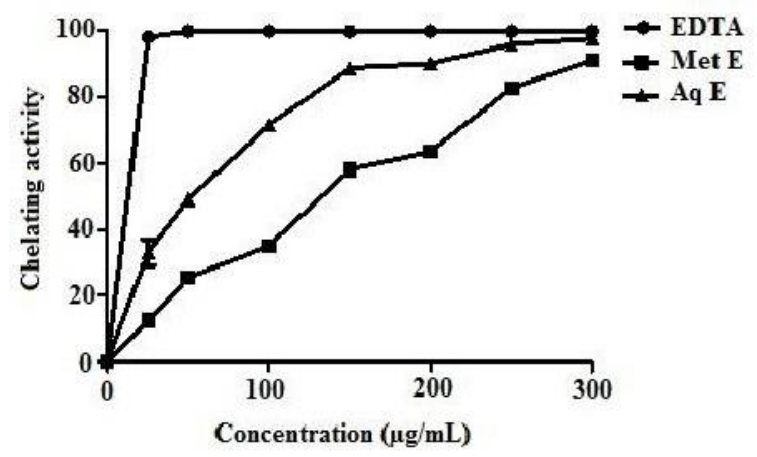

Figure 3 -

\section{Reducing Power}

The reductive activity of both extracts of G. alypum compared with BHT have been illustrate in Figure 4. The methanolic extract exerted a remarkable reducing power with $\mathrm{IC}_{50}$ of $50.4 \mu \mathrm{g} / \mathrm{mL}$, followed by the aqueous extract with an $\mathrm{IC}_{50}$ of $61 \mu \mathrm{g} / \mathrm{mL}$. This reductive activity is significant but less than that observed with BHT which showed an $\mathrm{IC}_{50}$ value of $17 \mu \mathrm{g} / \mathrm{mL}$.

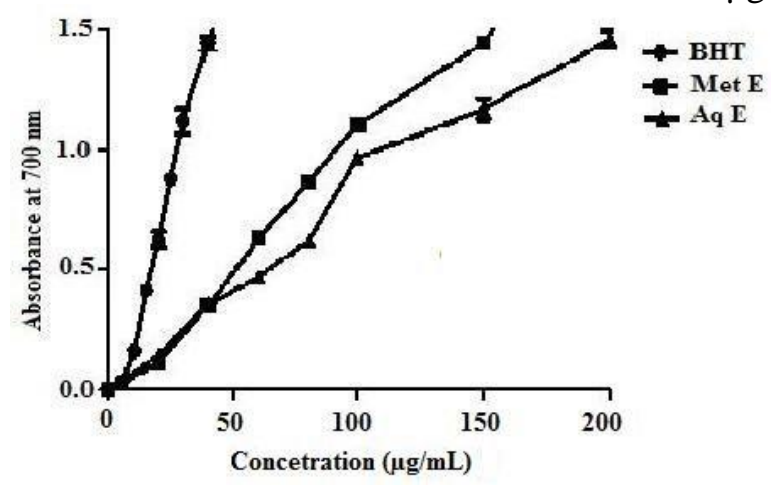

Figure 4 -

\section{Protective Effect of G. alypum Extracts Against Lipid Peroxidation}

Both extracts of $G$. alypum exerted a weak inhibition on linoleic acid peroxidation (Fig. 5). Indeed, at $100 \mu \mathrm{g} / \mathrm{mL}$, the methanolic extract showed only $42.45 \%$ of inhibition. Beyond this concentration, this inhibition was decreased. The aqueous extract was less efficient (4.03\%). 
Anti-oxidative damage of plant extracts

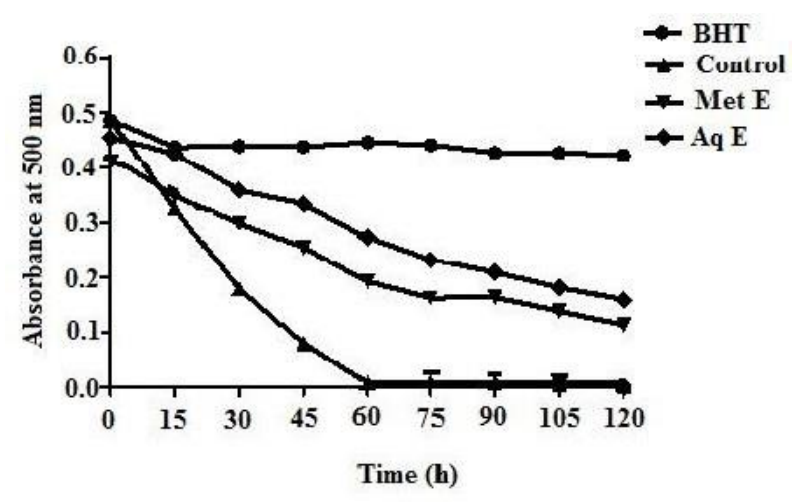

Figure 5 -

Protective Effect of G. alypum Extracts Against DNA Damage

Electrophoretic patterns of DNA after UV-photolysis of $\mathrm{H}_{2} \mathrm{O}_{2}$ in the presence or absence of $G$. alypum methanolic and aqueous extracts on agarose gel electrophoresis is shown in Figure 6. The conversion of supercoiled circular DNA (sc-DNA) to open circular (oc-DNA) derived from pBluescript M13+ DNA plasmid showed two bands on agarose gel electrophoresis (lane 1); the faster moving band corresponds to the native form of supercoiled circular DNA and the slower moving band corresponds to the open circular form. The UV irradiation of DNA in the presence of $\mathrm{H}_{2} \mathrm{O}_{2}$ (lane 2) resulted in the cleavage of sc-DNA to oc-DNA form and linear form (lin-DNA). It was noted that only UV treatment (lane 3), only $\mathrm{H}_{2} \mathrm{O}_{2}$ treatment (lane 4) and only UV treatment with 250 of extract (lane 5) could not induce damage to DNA, as observed with the mixture treatment; $\mathrm{UV}+\mathrm{DNA}+\mathrm{H}_{2} \mathrm{O}_{2}$ (lane 2). The addition of the extracts (lanes $6-9$ ) to this reaction mixture induced a partial recovery of sc-DNA. In fact, the intensity of sc-DNA bands scanned from the agarose gel electrophoretic patterns at $100,250,350$ and $500 \mu \mathrm{g} / \mathrm{mL}$ of G. alypum Met $\mathrm{E}$ and $\mathrm{Aq} \mathrm{E}$ was $45.88 \%, 53.77 \%, 70.91 \%$, and $84.24 \%$ and $37.75 \%, 70.88 \%$, $72.79 \%$ and $83.08 \%$, respectively compared with the untreated plasmid DNA.
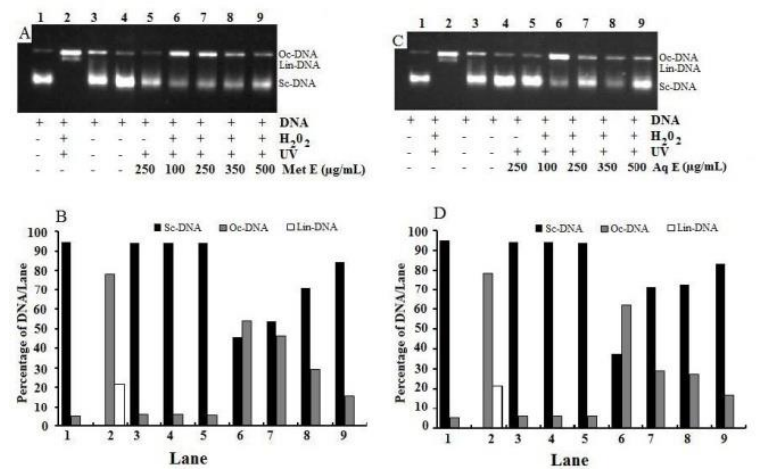

Figure 6 -

\section{Protective Effect of G. alypum Extracts Against Protein Oxidation}

Electrophoretic patterns of BSA after incubation for $3 \mathrm{~h}$ with $\mathrm{Fe}^{3+} / \mathrm{H}_{2} \mathrm{O}_{2} /$ ascorbic acid system in the absence or presence of different concentrations of methanolic and aqueous extracts of $G$. alypum, and the density of the corresponding bands were presented in Figure 7. The density of BSA band of the control induced by $\mathrm{Fe}^{3+} / \mathrm{H}_{2} \mathrm{O}_{2} /$ ascorbic acid decreased to $49.59 \%$. The treatment by G. alypum extracts exerted protective effect on BSA degradation induced by $\mathrm{Fe}^{3+} / \mathrm{H}_{2} \mathrm{O}_{2} /$ ascorbic acid system. Indeed, methanolic and aqueous extracts of G. alypums showed a concentration-dependent inhibition of protein oxidation. At 50, 100, 250, 500 and 
$1000 \mu \mathrm{g} / \mathrm{mL}$, the aqueous extract protected BSA very efficiently and restored the protein band intensity by $78.06 \%, 80.75,85.41 \%, 98.16 \%$ and $98.83 \%$ compared to the control level, respectively. At the same concentrations, the methanolic extract restored the BSA band intensity by 53.18\%, 56.2\%, 57.9\%, 74.29 and $76.97 \%$, respectively.
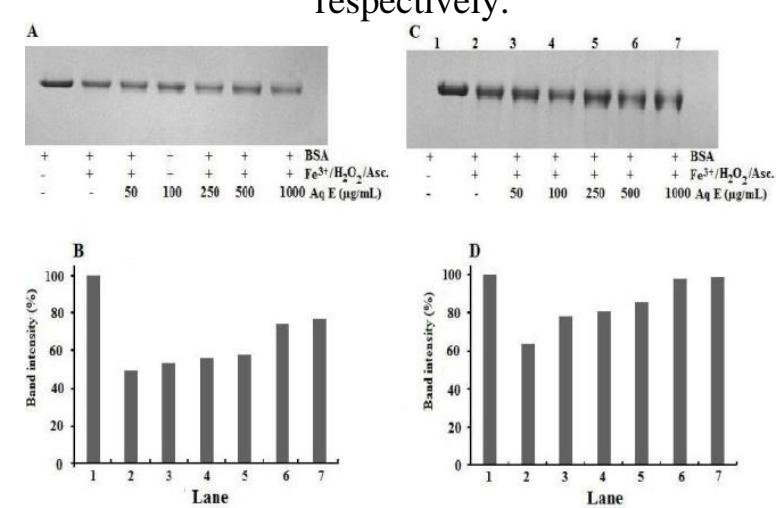

Figure 7 -

\section{DISCUSSION}

The identification of new natural products, which can provide protection against the generation of oxidative stress, may have important human health implications. In this study, we investigated whether G. alypum methanolic and aqueous extracts prevent ROS mediated damages to lipids, DNA and proteins, employing a variety of in vitro methods. Firstly, free radical scavenging activity, metal ion chelating, and reducing power of the extracts were tested. Results showed that both extracts were able to quench DPPH free radicals, and this activity is highly related to the amount of phenolic compounds (polyphenols, flavonoids and tannins). These compounds are electron donors and can react with DPPH free radicals to convert them to more stable products ${ }^{30,31}$. In addition, G. alypum extracts showed metal chelating activity and may serve as secondary antioxidants, by reducing the redox potential, thereby stabilizing the oxidized form of the ferrous ions. Ferrous ions are the most effective pro-oxidants, which lead to the hydroxyl ions ( $\left.\mathrm{HO}^{\circ}\right)$ production via Fenton reaction. Hydroxyl radicals are highly toxic and react with all kinds of biological macromolecules. Furthermore, both extracts exerted a remarkable reducing capacity, indicating that these extracts contain bioactive compounds that exhibit electrondonating capacity. The reducing capacity may serve as a significant indicator of the potent antioxidant activity of phenolics and flavonoids ${ }^{32}$.

Since both studied extracts showed significant anti-radical, chelating and reducing activities, so their protective activity against lipid, DNA and protein oxidation was evaluated in the current study.

Lipid peroxidation is preceded by radical mediated abstraction of the hydrogen atom from a methylene carbon on a polyunsaturated fatty acid side chain and it further proceeds with radical chain reaction. During this process, a number of compounds are formed such as malanoaldehyde (MDA), which used as a marker in the lipid peroxidation assay ${ }^{7}$. In this study, the lipid peroxidation was conducted using linoleic acid catalyzed by $\mathrm{Fe}^{2+}$-ascorbate. The transition of ferrous ions can stimulate lipid oxidation via Fenton reaction, and accelerate the reaction by decomposing the lipid hydroperoxides into peroxyl and alkoxyl radicals that can propagate the chain of lipid peroxidation ${ }^{33}$. Thus, minimizing ferrous ions may afford protection against oxidative damage by inhibiting the production of hydroxyl radicals $(\cdot \mathrm{OH})$, which is able to initiate free radical chain reactions ${ }^{30}$. This study showed that despite both studied extracts exerted significant scavenging, chelating and reducing activities they 
Anti-oxidative damage of plant extracts

were less effective on lipid peroxidation. This result may be due to the experimental conditions, in particular the time of measuring of MDA, since this assay is time consuming and therefore may not give accurate results due to degradation of the hydroperoxides before they converted to MDA in vitro during sample preparation ${ }^{34}$. Indeed, in another study, aqueous and methanolic extracts of G. alypum showed a significant potential to protect the unsaturated $\beta$-carotene molecules (data not shown) against free radicals attacks, by inhibiting strongly the linoleic acid peroxidation and then neutralizing free radicals formed in the system.

Similarly, the generation of oxidative damaged DNA is hypothesized to occur via production of ROS. The UV irradiation photolysis of $\mathrm{H}_{2} \mathrm{O}_{2}$ generates $\mathrm{OH}$ radicals, which attack DNA and resulting in the cleavage of the DNA strand, which is clearly visible in the control DNA (treated with $\mathrm{UV}+\mathrm{H}_{2} \mathrm{O}_{2}$ ). The scission of DNA strand was assessed by measuring the conversion of supercoiled circular DNA to open circular DNA and further to linear form derived. The $\mathrm{OH}$ radicals can damage all components of DNA molecules such as purine and pyrimidine bases and also the deoxyribose ${ }^{35}$, inhibiting the normal functions of the cell. Among different types of damages, DNA double strand breaks are the most deleterious, since they can lead to the loss of genetic material ${ }^{36}$. The treatment with G. alypum extracts protected the supercoiled double strand DNA from hydroxyl radical-induced strand scission. Indeed, in the presence of increasing concentration of these extracts, the proportion of both open circular DNA and linear DNA were significantly decreased, while the amount of the residual supercoiled DNA was recovered. This protective activity against DNA damage could be assigned to the presence of potent antioxidants in the extracts. It has been reported that the oxidative damage caused by exposure to $\mathrm{H}_{2} \mathrm{O}_{2}$ can be prevented by metal sequestering agents via chain-breaking antioxidants that scavenge the free radicals generated by metal ion-catalyzed decomposition of $\mathrm{H}_{2} \mathrm{O}_{2}$ 30. In fact, the studied extracts were found to be rich in phenolic acids and flavonoids, which are potent antioxidants. Phenolic compounds possess ideal chemical structure for reducing free radicals because they have phenolic hydroxyl groups that are prone to donate a hydrogen atom or an electron to a free radical, and extended conjugated aromatic system to delocalize an unpaired electron ${ }^{30}$. Sevgi et al. ${ }^{37}$ reported that phenolic acids possessed protective effects on pBR322 plasmid DNA against the mutagenic and toxic effects of UV and $\mathrm{H}_{2} \mathrm{O}_{2}$.

The most common mechanism for inducing protein oxidation is metal-catalysed reaction. Metal ions react with $\mathrm{H}_{2} \mathrm{O}_{2}$ in the so called Fenton reaction and produces hydroxyl radicals that attack neighboring amino acid residues ${ }^{38}$. ROS induce the cleavage of peptide bonds and then leads to different peptide fragmentation or protein-protein cross-linkages ${ }^{39}$. Moreover, amino acids can be modified directly via side chain reaction with ROS, methionine and cysteine are the most susceptible to oxidative changes due to high reaction susceptibility of the sulfur group in those amino acids ${ }^{39}$. In the present study, the metal-catalysed protein oxidation caused different peptide fragmentations. This oxidative damage was assessed using a common method (SDS-PAGE) for determination of protein fragments. Densitometric analysis of each protein band showed clearly that both aqueous and methanolic extracts of G. alypum protected significantly BSA against ROS attack and restored the protein band intensity. This ability to protect protein fragmentations is mainly due to the strong antioxidant activities exerted by both extracts. Generally, phenolic compounds are responsible for the antioxidant activities of plant extracts, and they have been reported as scavengers of ROS and chelators of metal cations that participate in hydroxyl radical formation ${ }^{30}$. Therefore, these compounds are viewed as promising therapeutic drugs for ROS inducing pathologies ${ }^{40,41,42}$. 


\section{CONCLUSION}

The overall results revealed that $G$. alypum possess high antioxidant activity. The presence of bioactive compounds such as polyphenols and flavonoids might be responsible for this activity. So, this plant can be considered as a good source of natural products that may be used in the treatment of different diseases associated to the oxidative stress.

\section{CONFLICT OF INTEREST}

Authors declare no conflict of interest in this study.

\section{ACKNOWLEDGEMENTS}

Authors acknowledge the Algerian Ministry of High Education for the financial support.

\section{REFERENCES}

1- Finkel T. Signal transduction by reactive oxygen species. J Cell Biol. 2012; 194: 17-15.

2- Reczek CR, Chandel NS. ROS-dependent signal transduction. Curr Opin Cell Biol. 2015; 33:8-13.

3- Jain M, Rivera S, Monclus EA, Synenki L, Zirk A, Eisenbart J, Feghali-Bostwick C, Mutlu, GM, Budinger GRS, Chandel NS. Mitochondrial reactive oxygens regulate transforming growth factor- $\beta$ signaling. J Biol Chem. 2013; 288: 770-777.

4- Krstic J, Trivanović D, Mojsilovic S, Santibanez JF. Transforming growth factor-Beta and oxidative stress interplay: implications in tumorigenesis and cancer progression. Oxid Med Cell Longev [internet]. 2015. Available from: http://dx.doi.org/10.1155/2015/654594.

5- Vara D, Pula G. Reactive oxygen species: physiological roles in the regulation of vascular cells. Curr Mol Med. 2014; 14: 1103-25.

6- Kayama Y, Raaz U, Jagger A, Adam M, Schellinger IN, Sakamoto M, Suzuki H, oyama K, Spin JM, Tsao PS. Diabetic Cardiovascular Disease Induced by Oxidative Stress. Int J Mol Sci. 2015; 16: 25234-25263.

7- Lobo V, Patil A, Phatak A, Chandra N. Free radicals, antioxidants and functional foods: Impact on human health. Pharmacogn Rev. 2010; 4: 118-126.

8- Ramana KV, Srivastava S, Singhal SS. Lipid peroxidation products in human health and disease. Oxid Med Cell Longev [internet]. 2013. Available from: http://dx.doi.org/10.1155/2013/583438.

9- Laguerre, M, Lecomte J, Villeneuve P. Evaluation of the ability of antioxidants to counteract lipid oxidation: Existing methods, new trends and challenges. Prog Lipid Res. 2007; 46: 244-282.

10-Jena NR. DNA damage by reactive species: Mechanisms, mutation and repair. J Biosci. 2012; 37: 503-517.

11-Chao M-R, Rossner P, Haghdoost JrS, Jeng HA, Hu C-W. Nucleic acid oxidation in human health and disease. Oxid Med Cell Longev [internet]. 2013. Published online 2013 Dec 25. Available from: http://doi.org/10.1155/2013/368651.

12- Davalli P, Mitic T, Caporali A, Lauriola A, D'Arca D. ROS, cell senescence, and novel molecular mechanisms in aging and age-related diseases. Oxid Med Cell Longev [internet]. Published online 2016 Avr 16. Available from: http://dx.doi.org/10.1155/2016/3565127.

13-Broustas CG, Lieberman HB. DNA damage response genes and the development of cancer metastasis. Radiat Res. 2014 ; 181: 111-130. 
Anti-oxidative damage of plant extracts

14-Schumacker PT. Reactive Oxygen species in cancer: A dance with the devil. Cancer Cell. 2015; $27: 156-157$.

15-Xu Y-J, Qiang M, Zhang J-L, Liu Y, He R-Q. Reactive carbonyl compounds (RCCs) cause aggregation and dysfunction of fibrinogen. Protein Cell. 2012 3: 627- 640.

16-Dasgupta A, Zheng J, Bizzozero OA. Protein carbonylation and aggregation precede neuronal apoptosis induced by partial glutathione depletion. ASN Neuro. 2012; 4: $\mathrm{e} 00084$.

17-Chen X, Chunyan Guo C, Kong J. Oxidative stress in neurodegenerative diseases. Neural Regen Res. 2012; 7: 376-385.

18-Rahman T, Hosen I, Towhidul Islam MM, Shekhar HU. Oxidative stress and human health. Adv Biosci

Biotechnol. 2012, 3: 997-1019.

19-Jouad H, Haloumi M, Rhiouani H, El Hilaly J, Eddoukes M. Ethnobotanical survey of medicinal plants used for the treatment of diabetes; cardiac and renal diseases in North centre region of Morocco (Fez-Boulmane). J Ethnopharmacol. 2001,77: 175-182.

20-Taleb-Dida N, Krouf D, Bouchenak M. Globularia alypum aqueous extract decreases hypertriglyceridemia and ameliorates oxidative status of the muscle, kidney, and heart in rats fed a high-fructose diet. Nutr Res. 2011; 31: 488-495.

21-Li HB, Cheng KW, Wong CC, Fan KW, Chen F, Jiang Y. Evaluation of antioxidant capacity and total phenolic content of different fractions of selected microalgae. Food Chem. 102: 2007; 771-776.

22-Bahorun T, Gressier B, Trotin F, Brunete C, Dine T, Vasseur J, et al. Oxygen species scavenging activity of phenolic extracts from hawthorn fresh plant organs and pharmaceutical preparations. Arzneimittel-Forsch. 1996; 46: 1086-1089.

23-Bate-Smith EC. Haemanalysis of tannins, the concept of relative astringency. Phytochemstry. 1973; 12: 907-912.

24-Abay G, Altun M, Koldas, S, Tüfekçi AR, Demirtas I. Determination of antiproliferative activities of volatile contents and HPLC profiles of Dicranum scoparium (Dicranaceae, Bryophyta). Comb Chem High Throughput Screen. 2015; 18:453-563.

25-Que F, Mao L, Pan X, Antioxidant activities of five Chinese rice wines and the involvement of phenolic compounds. Food Res Int. 2006; 39: 581-587.

26-Le K, Chiu F, $\mathrm{Ng} \mathrm{K}$. Identification and quantification of antioxidants in Fructus lycii. Food Chem. 2007; 105: 353-363.

27-Oyaizu M. Studies on products of browning reactions: antioxidative activities of browning reaction prepared from glucosamine. Jpn J Nutr. 1986; 4: 307-315.

28-Choi Y, Jeong HS, Lee J. Antioxidant activity of methanol extracts from some grains consumed in Korea. Food Chem. 2007; 103: 130-138.

29-Kizil G, kizil M, Ceken B,Yavuz M, Demir H. Protective activity of ethanol extracts of Hypericum scabrum L. and Hypericum retusum Aucher against the protein oxidation and DNA damage. Int J Food Prop. 2011; 14: 926-940.

30-Dai J, Mumper RJ. Plant phenolics: Extraction, analysis and their antioxidant and anticancer properties. Molecules. 2010; 15: 7313-7352.

31-Mathew S, Abraham TE, Zakaria ZA. Reactivity of phenolic compounds towards free radicals under in vitro conditions. J Food Sci Technol. 2015; 52: 5790 - 5798.

32-Jing L, Ma H, Fan P, Gao R, Jia Z. Antioxidant potential, total phenolic and total flavonoid contents of Rhododendron anthopogonoides and its protective effect on hypoxia-induced injury in PC12 cells. BMC. Complement Altern Med. 2015; 15: 287.

33-Ayala A, Munoz, MF, Arguelles S. Lipid peroxidation: production, metabolism, and signaling mechanisms of malondialdehyde and 4-Hydroxy-2-Nonenal. Oxid Med Cell Longev [internet]. 2014. Available from: http://dx.doi.org/10.1155/2014/360438.

34-Yamaguchi Y, Kunitomo M, Haginaka J. Assay methods of modified lipoproteins in plasma. J Chromatogr B. 2002; 781: 313-330.

35-Cadet J, Douki T, Ravanat J-L. Oxidatively generated damage to cellular DNA by UVB and UVA Radiation. Photochem Photobiol. 2015; 91: 140-155. 
36-Klaunig JE, Kamendulis LM, Hocevar BA. Oxidative stress and oxidative damage in carcinogenesis. Toxicol Pathol. 2010; 38: 96-109.

37-Sevgi K, Tepe B, Sarikurkcu C. Antioxidant and DNA damage protection potentials of selected phenolic acids. Food Chem Toxicol. 2015; 77: 200-204.

38-Davies MJ. Protein oxidation and peroxidation. Biochem J. 2016; 473: 805-825.

39-Zhang W, Xiao S, Ahn DU. Protein oxidation: basic principles and implications for meat quality. Crit Rev Food Sci Nutr. 2013; 53: 1191-201.

40-Carocho M, Ferreir IC. The role of phenolic compounds in the fight against cancer. Anticancer Agents Med Chem. 2013; 1236-1258.

41-Scapagnini G, Caruso C, Calabrese V. Therapeutic potential of dietary polyphenols against brain ageing and neurodegenerative disorders. Adv Exp Med Biol. 2010; 698: 27 35.

42-Yamada M, Ono K, Hamaguchi T, Noguchi-Shinohara M. Natural phenolic compounds as therapeutic and preventive agents for cerebral amyloidosis. Ad Exp Med Biol. 2015; 63: 79-94. 
Anti-oxidative damage of plant extracts

\section{Erratum}

In Article "Phenolic Content and Biomolecule Oxidation Protective Activity of Globularia alypum Extracts", with DOI number: http://dx.doi.org/10.1590/1678-4324-2017160409, published in journal Brazilian Archives of Biology and Technology, vol. 60, the 01 page.

That read:

“http://dx.doi.org/10.190/1678-4324-2017160409"

Read:

“"http://dx.doi.org/10.1590/1678-4324-2017160409" 